\title{
Seasonal changes in the nutritional status and yielding of Anthurium cultorum Birdsey. Part II. Microelements
}

\author{
Tomasz Kleiber ${ }^{l}$, Andrzej Komosa ${ }^{1}$, \\ Jolanta Krzyszkowska ${ }^{2}$, Krzysztof Moliński ${ }^{2}$ \\ ${ }^{1}$ Department of Horticultural Plant Nutrition \\ Poznań University of Life Sciences \\ Zgorzelecka 4, 60-198 Poznań, Poland \\ ${ }^{2}$ Department of Mathematical and Statistical Methods \\ Poznań University of Life Sciences \\ Wojska Polskiego 28, 60-637 Poznań, Poland \\ e-mail: tkleiber@up.poznan.pl
}

Key words: anthurium, indicator parts, plant analysis, vegetation period

\begin{abstract}
The experiment was carried out in the years 2002-2004. Its aim was the determination of the tendencies in the microelement nutritional status of the standard cultivars of Anthurium cultorum Birdsey ('Baron', 'Choco', 'Midori', 'Pistache', 'President', 'Tropical' from Anthura B.V.) in the autumn-winter and spring-summer vegetation periods. The plants were cultivated in expanded clay using a drop fertigation system with standard nutrition. A significant influence of the vegetation periods and the light conditions associated with them was found to be exerted on the microelement plant nutrition. In the autumn-winter period, characterized by light deficit, the plant age significantly modified the nutrition (increase or decrease of content with a plant's aging) with regard to zinc (-23.7\%), copper $(-25.8 \%)$
\end{abstract}


and boron (+25\%), while in the spring-summer period, iron (+12.9\%) and copper $(-21.7 \%)$ nutrition was modified. During the three years of the study, the autumnwinter period showed a significant increase of iron content (+9.8\%) with a simultaneous decrease of copper content (-6.5\%), in comparison with the springsummer period. The awareness of the cyclical nature of the changes in the nutritional status of plants, depending on the given vegetation season, supplies a valuable instrument in the interpretation of plant analyses for diagnostic purposes.

\section{INTRODUCTION}

Factors modifying the content of components in plants include, among others, plant cultivar (Mills and Scoggins 1998), chemical composition of nutrients (Dufour and Guérin 2005), type of substrate (Sonneveld and Voogt 1993, Anthura 1998), and the vegetation season and its light conditions (Breś and Jerzy 2004, Breś and Jerzy 2005, Kleiber et al. 2009). Determining plant nutrition status without the individual effect of each of the aforementioned components can be burdened by some essential mistakes, considering the wide ranges of microelement contents in the indicator parts of anthurium plants elaborated by other authors (among others by Anthura 1998, Mills and Scoggins 1998, Uchida 2000, Chen et al. 2003), as it makes the interpretation of chemical analyses difficult.

In the literature there is a lack of any articles discussing the influence of light conditions on the microelement contents in the indicator parts of anthurium. Meanwhile, Breś and Jerzy (2005) reported that in the case of potted chrysanthemums the improvement of light conditions significantly influenced the increased iron content in the indicator parts of the plant, while light deficit caused an improvement of the plant nutrition with regard to copper and boron.

The objective of the present study was the recognition of the natural tendencies in the microelement nutritional status of the standard cultivars of anthurium (Anthurium cultorum Birdsey) in the autumn-winter and spring-summer vegetation periods. The knowledge of these relations is necessary for a more precise analysis of plant nutrition status in production cultivations.

\section{MATERIAL AND METHODS}

The vegetation experiments were carried out in specialised production farms located in the Wielkopolska province. Two Venlo type greenhouses were equipped with modern fertigation systems for control and registration of climate, air humidity, and energy-saving curtains. The objects of the studies were the standard 
cultivars of anthurium (Anthurium cultorum Birdsey): 'Baron','Choco', 'Midori', 'Pistache', 'President' and 'Tropical' (Anthura B.V., the Netherlands) grown in expanded clay $(\varnothing 8-18 \mathrm{~mm})$. Cuttings grown in mineral wool pots $\left(75 \mathrm{~cm}^{3}\right)$ were planted into beds in the greenhouse on the $8-11^{\text {th }}$ of August 2000. The studies were started on the $15^{\text {th }}$ of January 2002 (on two-year-old plants) and were terminated on the 30th of November 2004 (four-year-old plants). One bed with $1.2 \times 46 \mathrm{~m}$ dimensions had an area of $55.2 \mathrm{~m}^{2}$, in which 14 plants were grown on one $\mathrm{m}^{2}$, i.e. 772 plants were planted in one bed. Agrotechnical treatments were carried out according to the current recommendations for anthurium.

In the vegetation experiments, drop irrigation in a closed system without nutrient recirculation was applied. The nutrients were distributed to the beds in drop-irrigation lines with drop emitters located every $20 \mathrm{~cm}$. Frequency and irrigation time depended on the season of the year. In summer, fertigation was applied 6-8 times, supplying 4-5 $\mathrm{dm}^{3}$ of nutrient per one $\mathrm{m}^{2}$; in winter, irrigation was applied 2-3 times, supplying 2-3 $\mathrm{dm}^{3}$. About $20 \%$ of the applied nutrients leaked out from the root zone. In order to provide adequate air humidity and substrate moisture, the cultivation was sprinkled with rainwater using microsprinklers. In the experiment, the standard nutrient for drop-irrigation of anthurium grown in inert substrate was $\left(\mathrm{mg} \mathrm{dm}^{-3}\right)$ : $\mathrm{N}^{-\mathrm{NH}_{4}}<14, \mathrm{~N}^{-\mathrm{NO}_{3}} 105, \mathrm{P} 31, \mathrm{~K} 176, \mathrm{Ca}$ 60, Mg 24, S-SO 4 48, Fe 0.840, Mn 0.160, Zn 0.200, B 0.220, Cu 0.032, Mo 0.048, pH 5.5-5.7, EC 1.5-1.8 mS cm$~^{-1}$ (Komosa 2000). Detailed data referring to light conditions, such as real insolation, solar radiation (irradiation, PAR) and plant yielding have been presented by Kleiber et al. (2009).

Samples of plant material were taken every two months between the $14^{\text {th }}$ and the $16^{\text {th }}$ day of the given months in the autumn-winter periods (in January, March and November) and in the spring-summer periods (in May, July and September) in the years 2002-2004. Anthurium indicator parts included fully developed leaves of plants from fresh cut flowers (De Kreij et al. 1990). The leaves were randomly selected from the total area of the beds, from plants characteristic of a given cultivar that were healthy, well yielding and without any symptoms of damages. One sample of a given cultivar consisted of 15-20 leaves taken in both experimental farms (the second farm was a replication for each variety). The collected leaves were dried at $45-50^{\circ} \mathrm{C}$ and were then ground. For the determination of the general forms of $\mathrm{Fe}, \mathrm{Mn}, \mathrm{Zn}, \mathrm{Cu}$, the plant material was mineralized in a mixture of nitric and perchloric acids $(3: 1 \mathrm{v} / \mathrm{v})$, while in the case of B it was muffled in the presence of calcium hydroxide (IUNG 1972). After the mineralization of the plant material, the $\mathrm{Fe}, \mathrm{Mn}, \mathrm{Zn}$ and $\mathrm{Cu}$ determinations were made using the AAS method (on Carl Zeiss, Jena - apparatus), and B was colorimetrically determined with curcumin. 
With the use of the linear model describing factorial analyses, microelement content was analysed in three successive cultivation years of six standard anthurium cultivars with the consideration of two vegetation seasons: the springsummer and the autumn-winter periods. For each cultivar, a multidimensional analysis of variance for two-directional classification was carried out. Furthermore, homogeneous groups of the studied years were created using Tukey's test (Morrison 1976). All numerical analyses were performed using the STATISTICA 8.0 package.

\section{RESULTS AND DISCUSSION}

The results of analyses of plant indicator parts are presented in Tables 1, 2, 3 and 4 . A significant effect of vegetation period on the plants' nutritional status with some of the microelements was found. A significantly smaller content of iron $(9.8 \%)$ was shown by plants in the spring-summer period, as compared with the autumn-winter period. The mean value from the studied cultivars showed a stable content of iron in the period of light deficit; however, in the spring-summer period, the value increased (Tabs 1 and 4). An essentially lower iron content was shown by the youngest plants (in 2002), while a higher iron content characterized the older plants (in 2003-2004).

No significant influence was found to be exerted by the vegetation period on the nutritional status with regard to manganese and zinc (Tabs 1,2 and 4). Both in the autumn-winter and the spring-summer periods, stable nutrition from both of these elements was found in the case of all of the studied cultivars.

A significant effect was found to be exerted by the vegetation season on plant nutrition with regard to copper (Tabs 2 and 4). A higher content of copper was determined in the spring-summer period, in comparison with the autumn-winter period. The age of plants was found to exert an essential effect on plant nutritional status in both vegetation periods. Both in the spring-summer and the autumn-winter periods, the least amount of copper content characterized the oldest plants (in 2004).

Similarly as in case of manganese and zinc, no significant influence was found to be exerted on the nutritional status with regard to boron (Tabs 3 and 4). The mean contents of boron for all studied cultivars (except for 'Baron') in both vegetation periods were similar. However, boron nutrition was significantly affected by the plants' age. In both vegetation periods, three-year-old plants had the highest boron content (in 2003). 
Table 1. Mean contents of iron and manganese in the indicator parts of anthurium ( $\mathrm{mg} \mathrm{kg}^{-1} \mathrm{~d} . \mathrm{m}$.), depending on the vegetation period

\begin{tabular}{|c|c|c|c|c|c|c|c|c|}
\hline \multirow{2}{*}{ Cultivar } & \multicolumn{4}{|c|}{ Autumn-Winter } & \multicolumn{4}{|c|}{ Spring-Summer } \\
\hline & $2002 *$ & 2003 & 2004 & Mean** & 2002 & 2003 & 2004 & Mean \\
\hline \multicolumn{9}{|c|}{$\mathrm{Fe}$} \\
\hline 'Baron' & 60.1 & 67.4 & 55.9 & $61.1 \mathrm{a}$ & 47.3 & $66.2 \mathrm{~b}$ & 59.2 & 57.5 \\
\hline 'Choco' & 38.8 & 48.9 & 45.4 & $44.4 \mathrm{a}$ & 35.6 & $41.5 \mathrm{a}$ & 49.5 & 42.2 \\
\hline 'Midori' & 49.2 & 51.0 & 42.2 & $47.5 \mathrm{a}$ & 35.5 & $45.8 \mathrm{a}$ & 51.7 & 44.3 \\
\hline 'Pistache' & 40.9 & 56.7 & 61.9 & $53.2 \mathrm{a}$ & 44.4 & $56.1 \mathrm{a}$ & 62.5 & 54.3 \\
\hline 'President' & 66.6 & 69.5 & 53.9 & $63.3 \mathrm{~b}$ & 43.1 & $58.5 \mathrm{a}$ & 50.8 & 50.8 \\
\hline 'Tropical' & 65.8 & 61.6 & 56.3 & $61.2 \mathrm{a}$ & 40.6 & $57.4 \mathrm{a}$ & 57.5 & 51.8 \\
\hline \multicolumn{9}{|c|}{$\mathrm{Mn}$} \\
\hline 'Baron' & 73.1 & 110.7 & 141.8 & 108.5 & 90.7 & 109.0 & 116.3 & 105.3 \\
\hline 'Choco' & 78.8 & 103.3 & 81.3 & 87.8 & 86.7 & 107.2 & 69.6 & 87.8 \\
\hline 'Midori' & 102.1 & 111.2 & 75.6 & 96.3 & 125.8 & 132.9 & 182.5 & 147.1 \\
\hline 'Pistache' & 80.5 & 85.7 & 81.5 & 82.6 & 82.0 & 120.4 & 79.3 & 93.9 \\
\hline 'President' & 76.4 & 80.2 & 66.7 & 74.4 & 94.6 & 108.4 & 81.6 & 94.9 \\
\hline 'Tropical' & 56.8 & 130.2 & 91.4 & 92.8 & 107.3 & 138.4 & 134.0 & 126.6 \\
\hline
\end{tabular}

*Values marked with different letters within vegetation periods differ significantly at $p=0.05$

$* *$ Mean values from the vegetation period marked with different letters differ significantly at $\mathrm{p}=0.05$

Table 2. Mean contents of zinc and copper in the indicator parts of anthurium ( $\mathrm{mg} \mathrm{kg}^{-1} \mathrm{~d} . \mathrm{m}$.), depending on the vegetation period

\begin{tabular}{|c|c|c|c|c|c|c|c|c|}
\hline \multirow{2}{*}{ Cultivar } & \multicolumn{4}{|c|}{ Autumn-Winter } & \multicolumn{4}{|c|}{ Spring-Summer } \\
\hline & $2002 *$ & 2003 & 2004 & Mean** & 2002 & 2003 & 2004 & Mean \\
\hline \multicolumn{9}{|c|}{$\mathrm{Zn}$} \\
\hline 'Baron' & 51.9 & 55.1 & 42.9 & 50.0 & 59.2 & 65.4 & 71.5 & 65.4 \\
\hline 'Choco' & 71.0 & 63.5 & 59.7 & 64.7 & 70.8 & 59.3 & 60.1 & 63.4 \\
\hline 'Midori' & 80.4 & 62.5 & 48.1 & 63.7 & 85.0 & 65.2 & 78.0 & 76.1 \\
\hline 'Pistache' & 52.0 & 53.6 & 45.3 & 50.3 & 60.3 & 55.9 & 52.3 & 56.2 \\
\hline 'President' & 76.7 & 64.8 & 54.3 & 65.3 & 78.3 & 61.6 & 58.0 & 66.0 \\
\hline 'Tropical' & 64.3 & 72.8 & 51.9 & 63.0 & 68.9 & 58.3 & 66.0 & 64.4 \\
\hline \multicolumn{9}{|c|}{$\mathrm{Cu}$} \\
\hline 'Baron' & $5.77 \mathrm{~b}$ & $5.77 \mathrm{~b}$ & 4.17 & 5.24 & $6.43 \mathrm{ab}$ & $7.44 \mathrm{~b}$ & 5.23 & $6.37 \mathrm{~b}$ \\
\hline 'Choco' & $7.32 \mathrm{~b}$ & $7.07 \mathrm{~b}$ & 4.51 & 6.30 & $6.69 a$ & $7.19 \mathrm{a}$ & 6.03 & $6.64 \mathrm{a}$ \\
\hline 'Midori' & $5.73 \mathrm{ab}$ & $7.04 \mathrm{~b}$ & 4.24 & 5.67 & $6.11 \mathrm{~b}$ & $6.40 \mathrm{~b}$ & 4.46 & $5.66 \mathrm{a}$ \\
\hline 'Pistache' & $5.34 \mathrm{a}$ & $5.55 \mathrm{a}$ & 4.94 & 5.28 & $5.60 \mathrm{a}$ & $6.39 \mathrm{a}$ & 5.26 & $5.75 \mathrm{a}$ \\
\hline 'President' & $5.87 \mathrm{a}$ & $6.55 \mathrm{a}$ & 4.52 & 5.64 & $6.31 \mathrm{ab}$ & $6.78 \mathrm{~b}$ & 4.54 & $5.88 \mathrm{a}$ \\
\hline 'Tropical' & $6.26 \mathrm{ab}$ & $6.50 \mathrm{~b}$ & 4.54 & 5.77 & $5.94 \mathrm{ab}$ & $6.68 \mathrm{~b}$ & 4.93 & $5.85 \mathrm{a}$ \\
\hline
\end{tabular}

*,**Explanations: see Table 1 
Changes of microelement contents and yielding of anthurium

Table 3. Mean contents of boron in the indicator parts of anthurium $\left(\mathrm{mg} \mathrm{kg}^{-1} \mathrm{~d} . \mathrm{m}\right.$.), depending on the vegetation period

\begin{tabular}{lcccccccc}
\hline \multirow{2}{*}{ Cultivar } & \multicolumn{3}{c}{ Autumn-Winter } & \multicolumn{5}{c}{ Spring-Summer } \\
\cline { 2 - 9 } & $2002^{*}$ & 2003 & 2004 & Mean** & 2002 & 2003 & 2004 & Mean \\
\hline 'Baron' & 75.2 & 84.3 & 79.3 & $79.6 \mathrm{~b}$ & 56.1 & $77.5 \mathrm{a}$ & 58.2 & 63.9 \\
'Choco' & 66.1 & 89.9 & 79.5 & $78.5 \mathrm{a}$ & 53.5 & $89.1 \mathrm{~b}$ & 64.8 & 69.1 \\
'Midori' & 62.9 & 88.3 & 77.5 & $76.2 \mathrm{a}$ & 70.6 & $91.9 \mathrm{a}$ & 73.2 & 78.6 \\
'Pistache' & 56.6 & 95.9 & 81.0 & $77.8 \mathrm{a}$ & 67.1 & $86.3 \mathrm{~b}$ & 74.3 & 75.9 \\
'President' & 51.9 & 76.9 & 75.0 & $67.9 \mathrm{a}$ & 61.9 & $97.5 \mathrm{~b}$ & 56.7 & 72.0 \\
'Tropical' & 54.6 & 80.0 & 66.9 & $67.2 \mathrm{a}$ & 74.1 & $94.0 \mathrm{~b}$ & 56.2 & 74.8 \\
\hline
\end{tabular}

***Explanations: see Table 1

Table 4. Mean contents of microelement in the indicator parts of anthurium ( $\mathrm{mg} \mathrm{kg}^{-1} \mathrm{~d} . \mathrm{m}$.), depending on the vegetation period

\begin{tabular}{lcccccccc}
\hline \multirow{2}{*}{ Nutrient } & \multicolumn{4}{c}{ Autumn-Winter } & \multicolumn{3}{c}{ Spring-Summer } \\
\cline { 2 - 9 } & $2002 *$ & 2003 & 2004 & Mean** & 2002 & 2003 & 2004 & Mean \\
\hline $\mathrm{Fe}$ & $53.6 \mathrm{a}$ & $59.2 \mathrm{a}$ & $52.6 \mathrm{a}$ & $55.1 \mathrm{~B}$ & $41.1 \mathrm{a}$ & $54.3 \mathrm{~b}$ & $55.2 \mathrm{~b}$ & $50.2 \mathrm{~A}$ \\
$\mathrm{Mn}$ & $78.0 \mathrm{a}$ & $103.6 \mathrm{a}$ & $89.7 \mathrm{a}$ & $90.4 \mathrm{~A}$ & $97.9 \mathrm{a}$ & $119.4 \mathrm{a}$ & $110.6 \mathrm{a}$ & $109.3 \mathrm{~A}$ \\
$\mathrm{Zn}$ & $66.1 \mathrm{~b}$ & $62.1 \mathrm{ab}$ & $50.4 \mathrm{a}$ & $59.5 \mathrm{~A}$ & $70.4 \mathrm{a}$ & $61.0 \mathrm{a}$ & $64.3 \mathrm{a}$ & $65.3 \mathrm{~A}$ \\
$\mathrm{Cu}$ & $6.05 \mathrm{~b}$ & $6.41 \mathrm{~b}$ & $4.49 \mathrm{a}$ & $5.65 \mathrm{~A}$ & $6.18 \mathrm{~b}$ & $6.81 \mathrm{c}$ & $5.08 \mathrm{a}$ & $6.02 \mathrm{~B}$ \\
$\mathrm{~B}$ & $61.2 \mathrm{a}$ & $85.9 \mathrm{~b}$ & $76.5 \mathrm{~b}$ & $74.5 \mathrm{~A}$ & $63.9 \mathrm{a}$ & $89.4 \mathrm{~b}$ & $63.9 \mathrm{a}$ & $72.4 \mathrm{~A}$ \\
\hline
\end{tabular}

*Values in rows marked with different letters within vegetation periods differ significantly at $p=0.05$

$* *$ Mean values from the vegetation period marked with different letters differ significantly at $\mathrm{p}=0.05$

Kleiber et al. (2009) found a significant effect by the vegetation period on anthurium nutritional status with regard to macroelements. In the spring-summer period, together with the improvement of light conditions (PAR, solar radiation and real insolation), the aforementioned authors found an increase in potassium content and a decrease of phosphorus in plant indicator parts, as compared with the autumn-winter period. The present work also found a significant effect exerted by the vegetation periods on the content of some microelements. In the spring-summer period, an essential increase of copper content was found with a simultaneous decrease of iron content in the plant indicator parts. Inverted results of the influence of light conditions on the microelement nutritional status of plants were reported by Breś and Jerzy (2005). These authors found that together with the improvement of light conditions, the iron content in the indicator parts of chrysanthemums increased significantly. In turn, a light deficit caused an improvement of plant nutrition with regard to copper and boron.

The results of chemical analyses of the plant indicator parts were compared with the ranges of microelement contents reported by other authors in other climatic conditions (Tab. 5). Iron nutritional status was within the ranges reported by Anthura (1998), Mills and Scoggins (1998). The contents of manganese were convergent with those reported by Mills and Scoggins (1998), Uchida (2000) and Chen et al. (2003). Nutrition with regard to zinc was within the ranges reported by 
Anthura (1998); in younger leaves, by Mills and Scoggins (1998) and by Chen et al. (2003). The amounts of copper were within the ranges recommended for mature leaves by Mills and Scoggins (1998). The nutritional status of boron was correct (Uchida 2000, Chen et al. 2003). Generally, the microelement contents determined in the present study were in a comparatively high degree within significantly wider ranges than those recommended by other authors. This fact may be a testimony of the comparatively small influence exerted by the light conditions occurring in Poland on the nutritional status of microelements in anthurium.

Table 5. Comparison of results of chemical analysis of index parts of anthurium to the range of micronutrient levels recommended by the selected authors

\begin{tabular}{|c|c|c|c|}
\hline \multirow[t]{2}{*}{ Nutrient } & \multirow{2}{*}{$\begin{array}{l}\text { Recommended values } \\
\mathrm{mg} \mathrm{kg}^{-1} \text { d.m. }\end{array}$} & \multicolumn{2}{|c|}{$\begin{array}{l}\text { Percent of results incorporated in the range } \\
\text { of recommended contents }\end{array}$} \\
\hline & & Autumn-Winter & Spring-Summer \\
\hline \multicolumn{4}{|c|}{ Mills and Scoggins (1998) ${ }^{1}$} \\
\hline$\overline{\mathrm{Fe}}$ & $20.7-90.0^{(a)}$ & 100.0 & 100.0 \\
\hline $\mathrm{Mn}$ & $41.0-237.0$ & 100.0 & 100.0 \\
\hline $\mathrm{Zn}$ & $41.0-98.1$ & 100.0 & 100.0 \\
\hline $\mathrm{Cu}$ & $10.3-25.0$ & 0.0 & 0.0 \\
\hline $\mathrm{B}$ & $12.0-25.0$ & 0.0 & 0.0 \\
\hline \multicolumn{4}{|c|}{ Mills i Scoggins (1998) } \\
\hline$\overline{\mathrm{Fe}}$ & $28.0-76.6^{(b)}$ & 100.0 & 100.0 \\
\hline $\mathrm{Mn}$ & $44.0-193.3$ & 100.0 & 100.0 \\
\hline $\mathrm{Zn}$ & $17.0-57.5$ & 50.0 & 11.1 \\
\hline $\mathrm{Cu}$ & $4.0-13.8$ & 100.0 & 100.0 \\
\hline B & $11.0-27.0$ & 0.0 & 0.0 \\
\hline \multicolumn{4}{|c|}{ Uchida $(2000)^{1}$} \\
\hline$\overline{\mathrm{Fe}}$ & $50.0-400.0$ & 66.7 & 55.6 \\
\hline $\mathrm{Mn}$ & $50.0-1500.0$ & 100.0 & 100.0 \\
\hline $\mathrm{Zn}$ & - & - & - \\
\hline $\mathrm{Cu}$ & - & - & - \\
\hline B & $25.0-135.0$ & 100.0 & 100.0 \\
\hline \multicolumn{4}{|c|}{ Chen et al. $(2003)^{1}$} \\
\hline$\overline{\mathrm{Fe}}$ & $50.0-400.0$ & 66.7 & 55.6 \\
\hline $\mathrm{Mn}$ & $40.0-500.0$ & 100.0 & 100.0 \\
\hline $\mathrm{Zn}$ & $20.0-200.0$ & 100.0 & 100.0 \\
\hline $\mathrm{Cu}$ & $5.0-40.0$ & 66.7 & 83.3 \\
\hline $\mathrm{B}$ & $20.0-100.0$ & 100.0 & 100.0 \\
\hline \multicolumn{4}{|c|}{ Anthura $(1998)^{2}$} \\
\hline$\overline{\mathrm{Fe}}$ & $28.0-112.0$ & 100.0 & 100.0 \\
\hline $\mathrm{Mn}$ & $38.0-109.0$ & 77.8 & 55.6 \\
\hline $\mathrm{Zn}$ & $46.0-131.0$ & 88.9 & 100.0 \\
\hline $\mathrm{Cu}$ & $6.3-12.7$ & 27.8 & 50.0 \\
\hline $\mathrm{B}$ & $54.0-76.0$ & 38.9 & 55.6 \\
\hline
\end{tabular}

Climate: 1 - tropical, marine climate; 2 - temperate warm marine climate a - young leaves, in $90 \%$ ripe, pale-green, 10 days before full maturity

$\mathrm{b}-$ mature leaves, dark-green, with a growing flower mature in $75 \%$ 


\section{CONCLUSIONS}

1. A significant influence of vegetation periods was found to be exerted on the nutritional status of plants with regard to microelements. In the spring-summer period, there was a significant decrease in the content of iron, while copper content increased, in comparison with the autumn-winter season. At the same time, a tendency towards an improvement in plant nutrition with regard to manganese and zinc was observed.

2. A significant influence by plant aging on the nutritional status with regard to microelements in the spring-summer period was found. With the aging of the plants, the content of copper decreased in the plant indicator parts, while the content of iron increased.

3. Plant aging exerted an influence on the nutritional status with regard to microelements in the autumn-winter period. In the case of older plants, the boron content increased, but at the same time, zinc and copper contents decreased.

\section{ACKNOWLEDGEMENTS}

The study was co-financed by the State Committee for Scientific Research (KBN), grant No. 0381/P06/2004.

\section{REFERENCES}

ANTHURA, 1998. Cultivation guide Anthurium. Anthura: 43.

BREŚ W., JERZY M., 2004. Effect of the planting date on macronutritional status of pot chrysanthemums from the Time group in all-year-round culture. Folia Hort. 16/2: 127-139.

BREŚ W., JERZY M., 2005. Effect of the planting date on micronutritional status of pot chrysanthemums from the Time Group in all-year round culture. Acta Scien. Pol., Hort. Cult. 4(1): 39-46.

Chen J., McConnell D.B., Henny R., EveritT K.C., 2003. Cultural guidelines for commercial production of interiorscape anthurium. Environ. Hort. Dept. Florida Coop. Ext. Serv., Univ. of Florida.

De Kreij C., Sonneveld C., Warmenhoven M.G., Straver N., 1990. Guide values for nutrient element contents of vegetables and flowers under glass. Voedingsoplossingen Glastuinbouw: 23. 
DUfOUR L., GUÉRIN V., 2005. Nutrient solution effects on the development and yield of Anthurium andreanum Lind. in tropical soilless conditions. Sci. Hort. 105: 269-282.

IUNG, 1972. Metody badań laboratoryjnych w stacjach chemiczno-rolniczych. Część II. Badanie materiału roślinnego. IUNG, Puławy: 25-83.

Kleiber T., Komosa A., Krzyszkowska J., Moliński K., 2009. Seasonal changes in the nutritional status and yielding of Anthurium cultorum Birdsey. Part I. Macroelements. Folia Hort. 21/1: 81-93.

KomOSA A., 2000. Analiza podłoża i roślin jako wskaźniki odżywiania anturium. V Konf. dla Producentów Anturium, ISiK, Skierniewice, 12-13 kwietnia: 24-30.

MiLLS H.A., SCOGGINS H.L., 1998. Nutritional levels for anthurium: young versus mature leaves. J. Plant Nutr. 21(1): 199-203.

MORRISON D.F., 1976. Multivariate statistical methods. McGraw-Hill, Book Company.

SonNEVEld C., Voogt W., 1993. The concentration of nutrients for growing Anthurium andreanum in substrate. Acta Hort. 342: 61-67.

UCHIDA R., 2000. Recommended plant tissue nutrient levels for some vegetable, fruit and ornamental foliage and flowering plants in Hawaii. Plant Nutrient Management in Hawaii's Soils. College of Tropical Agriculture and Human Resources, University of Hawaii at Manoa: 57-64.

\section{SEZONOWOŚĆ ZMIAN STANU ODŻYWIENIA ORAZ PLONOWANIA ANTHURIUM CULTORUM BIRDSEY.}

\section{CZ. II. MIKROELEMENTY}

Streszczenie: Badania przeprowadzono w latach 2002-2004. Ocenie poddano stan odżywienia mikroelementami standardowych odmian Anthurium cultorum Birdsey ('Baron', 'Choco', 'Midori', 'Pistache', 'President', 'Tropical' from Anthura B.V.) w 2 okresach wegetacji, różniących się istotnie warunkami świetlnymi: jesienno-zimowym i wiosenno-letnim. Rośliny uprawiano w keramzycie z zastosowaniem fertygacji kroplowej pożywką standardową. Wykazano istotny wpływ warunków świetlnych na stan odżywienia roślin mikroelementami. W okresie jesienno-zimowym, charakteryzującym się deficytem światła, stan odżywienia roślin (wzrost lub spadek zawartości): cynkiem $(-23,7 \%)$, miedzią $(-25,8 \%)$ i borem $(+25 \%)$, a $\mathrm{w}$ okresie wiosenno-letnim żelazem $(+12,9 \%)$ i miedzią $(-21,7 \%)$ zależał istotnie od wieku roślin. Dla średniej z 3 lat badań stwierdzono $\mathrm{w}$ okresie jesienno-zimowym istotny wzrost zawartości żelaza $(+9,8 \%)$, przy jednoczesnym obniżeniu zawartości miedzi $(-6,5 \%)$ w porównaniu 
z okresem wiosenno-letnim. Znajomość cykliczności zmian stanu odżywienia roślin, w zależności od okresu wegetacji jest wartościowym narzędziem w interpretacji wyników analizy roślin w celach diagnostycznych.

Received November 24, 2008; accepted July 28, 2009 